\title{
KAJIAN ORIENTASI SPASIAL PADA KAWASAN WISATA GAMPONG JABOI DI KOTA SABANG
}

\author{
Rinaldi Mirsa $^{1 *}$, Eri Saputra ${ }^{2}$, Tri Agusti Ningsih ${ }^{3}$ \\ ${ }^{1 *}$ Program Studi Arsitektur Universitas Malikussaleh, email: rinaldi@unimal.ac.id \\ ${ }^{2}$ Program Studi Arsitektur Universitas Malikussaleh, email: erisaputra@unimal.ac.id \\ ${ }^{3}$ Program Studi Arsitektur Universitas Malikussaleh, email: triagustinningsih2@gmail.com
}

\begin{abstract}
ABSTRAK
Orientasi spasial adalah konsep abstrak yang di dalamnya meliputi hubungan spasial kemampuan mengamati hubungan posisi objek dalam ruang. Dalam orientasi spasial yang berhubungan dengan ruang yaitu konstelasi, konstelasi yang dimaksud menjelaskan tentang susunan, bentuk, ruang, tatanan, pola. Kota Sabang merupakan wilayah paling barat di Indonesia yang memiliki dua kecamatan Sukajaya dan Sukakarya serta terbagi menjadi delapan belas Gampong salah satunya Gampong Jaboi, potensi yang terdapat yaitu potensi objek wisata alam dan buatan diantaranya: Pemandian Air Panas, Gunung Berapi, Wonderfull Point, Pantai Batee Tamon, Menara Mercusuar, Taman Pasi. Permasalahan pada penelitian untuk melihat sebuah objek dalam ruang atau kawasan meliputi susunan, bentuk, tatanan, ruang, pola, hubungan dalam objek wisata Gampong Jaboi. Tujuan penelitian ini untuk mengetahui bagaimana konstelasi penataan objek wisata yang baik pada kawasan wisata Gampong Jaboi. Penelitian menggunakan metode kualitatif dengan pengumpulan data sekunder dan primer yaitu pengamatan secara langsung kawasan wisata Gampong Jaboi. Konsepnya dijelaskan dalam bentuk variable konstelasi. Berdasarkan hasil penelitian menunjukkan bahwa pola yang terjadi di dalam kawasan wisata Gampong Jaboi terdiri dari empat pola yang saling berhubungan antara wisata yang satu dengan yang lain.
\end{abstract}

\section{Kata kunci: Orientasi Spasial, Konstelasi, Pola, Wisata, Sabang}

Info Artikel:

Dikirim: 7 Juli 2021; Revisi: 12 Agustus 2021; Diterima: 26 September 2021; Diterbitkan: 30 September 2021

(C2021 The Author(s). Published by Arsitekno, Architecture Program, Universitas Malikussaleh, Aceh, Indonesia under the Creative Commons Attribution 4.0 International License (https://creativecommons.org/licenses/by/4.0/).

\section{PENDAHULUAN}

Sabang dikenal sebagai Pulau Weh yang merupakan pulau kecil yang indah terletak dibagian barat pulau Sumatra. Kota Sabang terdiri dari 2 (dua) Kecamatan: Kecamatan Sukajaya dan Kecamatan Sukakarya, kekayaan alam yang berwujud wisata pantai bawah laut dan wisata alam, kedua wisata tersebut bisa dikunjungi di kawasan Jaboi atau lebih dikenal dengan Gampong Jaboi. Gampong Jaboi adalah sebuah desa yang terletak di Kecamatan Sukajaya, Kota Sabang. Gampong ini terkenal dengan beberapa destinasi wisata yang menjadi andalan untuk memikat pengunjung dari dalam maupun luar negeri. Gampong Jaboi mempunyai luas 490,14 Ha dan mempunyai jumlah penduduk 718 jiwa dan158 KK [1].

Kawasan Gampong Jaboi terdapat beberapa objek wisata yang bisa memikat wisatawan berkunjung diantaranya wisata alam meliputi wisata Gunung Merapi, Wonderfull Point dan Pemandian Air Panas, Menara Mercusuar, Taman Pasi, dan Pantai Batee Tamon. 


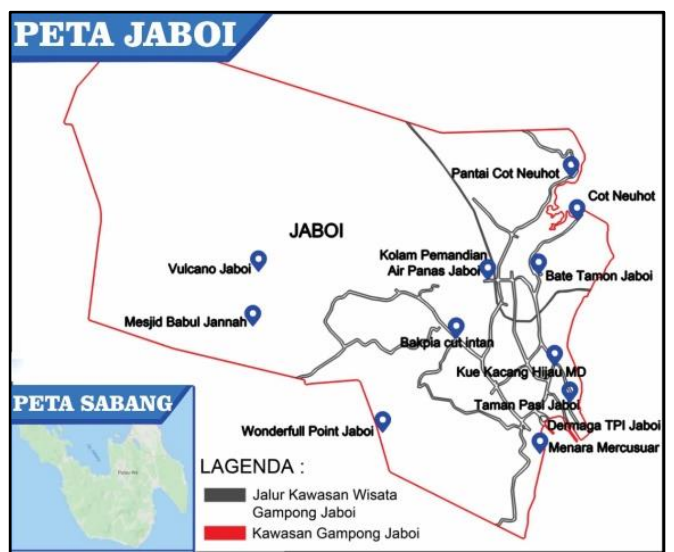

Gambar 1. Peta Gampong Jaboi-Kota Sabang

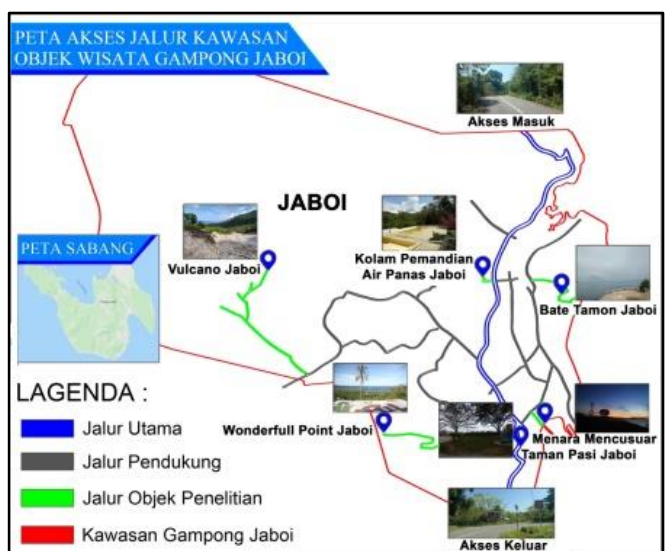

Gambar 2. Peta Akses Jalur Kawasan Objek Wisata Gampong Jaboi

Objek kawasan wisata pada Gampong Jaboi memiliki potensi yang besar untuk dikembangkan dari segi keindahan alam hingga tujuan pengunjung wisata, oleh karena itu masih diperlukan perhatian khusus dari pemerintahan dan warga setempat, misalnya perlu adanya hubungan setiap objek wisata, susunan, dan penataan objek dalam kawasan wisata sehingga membuat peneliti ingin mengkaji objek wisata tersebut dengan menggunakan konsep Orientasi Spasial dan mengambil teori Konstelasi untuk meneliti sebuah objek dalam ruang atau kawasan.

Kemampuan spasial adalah untuk melihat dunia visual sosial secara akurat dan kemampuan untuk melakukan perubahan dengan penglihatan, kemampuan ini berkaitan dengan warna, garis bangun, bentuk, ruang, serta hubungannya [2]. Teori konstelasi berkembang menjadi suatu "Bahasa Pola" yang dapat diartikan pertalian dengan berbagai situasi dari bagian-bagian suatu tipe bangunan tertentu, bahasa pola menyarankan pemecahan formal bagi fungsi-fungsi tertentu [3]. Ruang wilayah atau region pariwisata dapat melingkupi satu atau beberapa kota besar, menengah dan kecil yang melayani satu atau lebih destinasi pariwisata yang terhubungkan oleh prasarana transportasi dengan destinasi tidak terbatas dalam satu satuan administrasif [4]. Daya tarik wisata disebut objek wisata merupakan potensi yang menjadi pendorong kehadiran wisatawan ke suatu daerah tujuan wisata [5]. Objek dan daya tarik wisata adalah suatu bentukan dari aktivitas dan fasilitas yang berhubungan yang dapat menarik minat wisatawan atau pengunjung datang ke suatu daerah tertentu [6]. Sarana wisata merupakan perusahaan-perusahaan yang memberikan pelayanan kepada wisatawan, baik secara langsung maupun tidak [7].

Kawasan wisata Gampong Jaboi menuntun peneliti untuk mengkaji bagaimana konstelasi yang terjadi mulai dari susunan, tatanan, bentuk, ruang, hubungan, hingga pola di dalam kawasan wisata Gampong Jaboi. Melalui pemahaman tentang konstelasi, peneliti ingin mengetahui konstelasi yang terjadi di dalam kawasan wisata Gampoi Jaboi, Uraian ini akan dibahas dalam bentuk variable konstelasi. 


\section{METODE PENELITIAN}

Metode penelitian ini menggunakan metode pendekatan kualitatif dengan pengumpulan data sekunder dan primer yaitu pengamatan secara langsung bagaimana konstelasi penataan pada setiap kawasan wisata Gampong Jaboi, mulai dari wisata alam dan wisata buatan. Konsep konstelasi dapat diuraikan ke dalam bentuk variable-variabel dari unsur pembentuknya.

\section{HASIL DAN PEMBAHASAN}

\subsection{Susunan Konstelasi}

Susunan objek wisata dalam kawasan wisata Gampong Jaboi dapat dilihat, Untuk daerah wisata Gampong Jaboi rute pertama Pemandian Air Panas Jaboi, kemudian rute atas wisatawan akan berjumpa dengan objek wisata Gunung Berapi, selanjutnya disusul dengan objek wisata Wonderfull Point. Wisatawan yang memilih rute bawah akan berjumpa dengan objek wisata Pantai Batee Tamon, dan disusul dengan objek wisata Menara Mercusuar, setelah semua rute sudah dilalui oleh wisatawan maka objek wisata yang terakhir yaitu Taman Pasi.

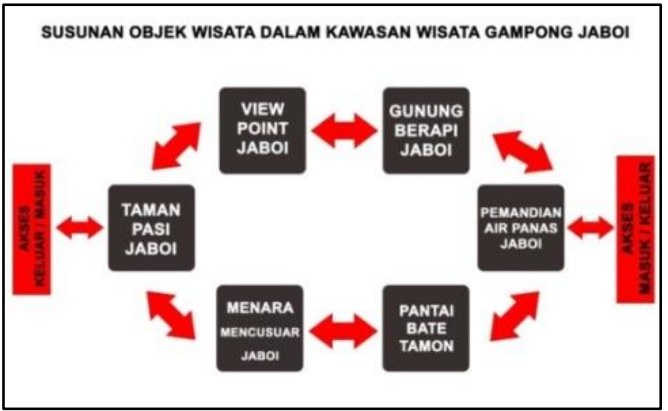

Gambar 3. Susunan Objek Wisata Dalam Kawasan Wisata Gampong Jaboi

\subsection{Bentuk Konstelasi}

Pada objek wisata dalam kawasan wisata Gampong Jaboi memiliki bentuk yang terbentuk secara alami hampir seluruh objek wisata, untuk beberapa objek wisata terbentuk karena masyarakat Gampong Jaboi yang membangun objek wisata tersebut.

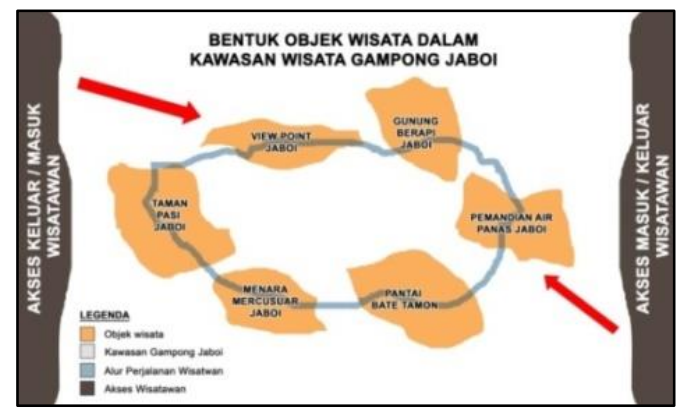

Gambar 4. Bentuk Objek Wisata Dalam Kawasan Wisata Gampong Jaboi

\subsection{Tatanan Konstelasi}

\section{Tatanan Konstelasi Pada Objek Wisata Pemandian Air Panas}

Tatanan objek wisata Pemandian Air Panas pada kawasan wisata Gampong Jaboi dapat dilihat sudah memiliki fasilitas atau kebutuhan ruang yang cukup memadai. Pengembangan objek wisata harus mencakup lima unsur yang terpenting agar wisatawan dapat menikmati kunjungannya ke suatu objek wisata, antara lain atraksi, fasilitas, infrastruktur, transportasi dan hospitality [8]. 


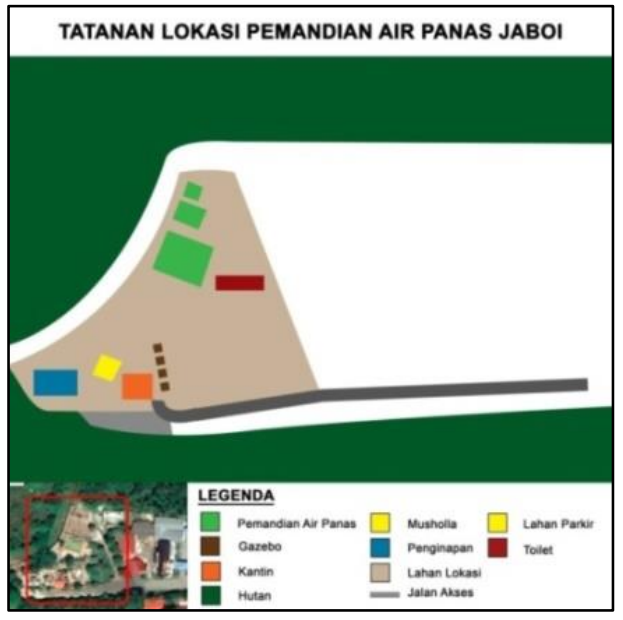

Gambar 5. Tatanan Objek Wisata Pemandian Air Panas

\section{Tatanan Konstelasi Pada Objek Wisata Gunung Berapi}

Tatanan objek wisata dalam Gunung Berapi Jaboi terdapat beberapa lokasi objek wisata, untuk area kawah satu berada dekat akses masuk kawasan objek wisata Gunung Berapi, selanjutnya kawah dua sampai kawah empat diikuti jalan.

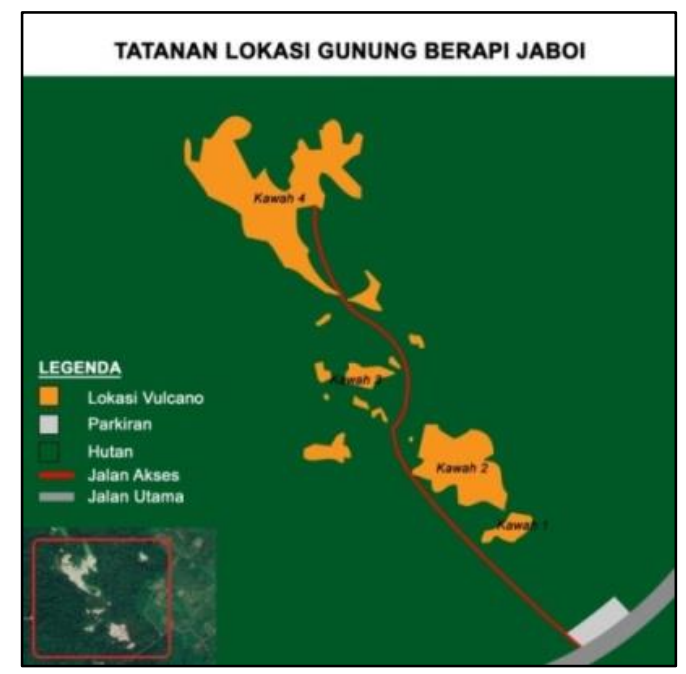

Gambar 6. Tatanan Objek wisata Gunung Berapi

\section{Tatanan Konstelasi Pada Objek Wisata Wonderfull Point}

Tatanan dalam objek wisata Wonderfull Point mempunyai beberapa view atau panorama, area view point satu dan area view point dua, fasilitas di dalam objek wisata terdapat shalter dan area parkir yang memadai. Objek wisata Wonderfull Point ini dikelilingi oleh hutan lindung. 


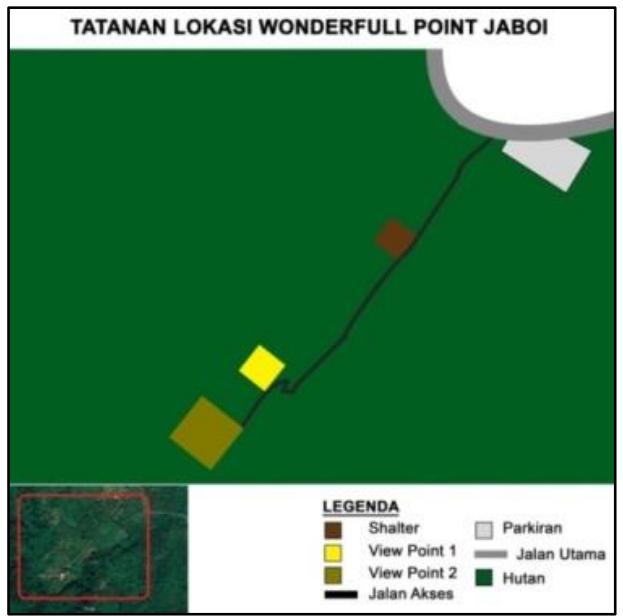

Gambar 7. Objek wisata Wonderfull Point

\section{Tatanan Konstelasi Pada Objek Wisata Pantai Batee Tamon}

Tatanan dalam objek wisata Pantai Batee Tamon memiliki dataran yang sekaligus digunakan untuk area parkir bagi wisatawan yang mengunjungi objek tersebut. Area kawasan objek wisata Pantai Batee Tamon ini juga dikelilingi oleh hutan lindung yang sangat luas.

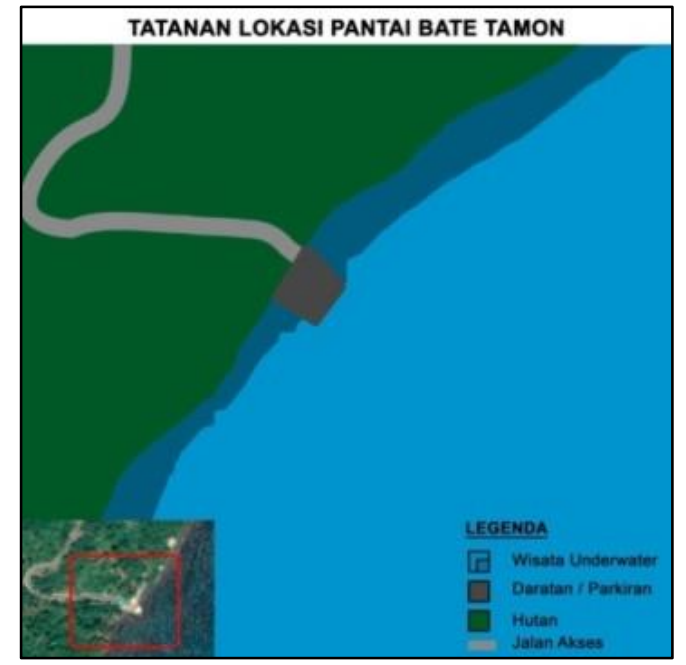

Gambar 8. Tatanan Objek wisata Wonderfull Point

\section{Tatanan Konstelasi Pada Objek Wisata Menara Mercusuar}

Tatanan objek wisata Menara Mercusuar Jaboi ini dikelilingi oleh laut dan hutan lindung yang dilindungi oleh masyarakat setempat dan pemerintah, bukan hanya itu tatanan objek wisata yang berada paling ujung antara laut dan gunung, sehingga wisatawan dapat menikmati panorama matahari terbit. 


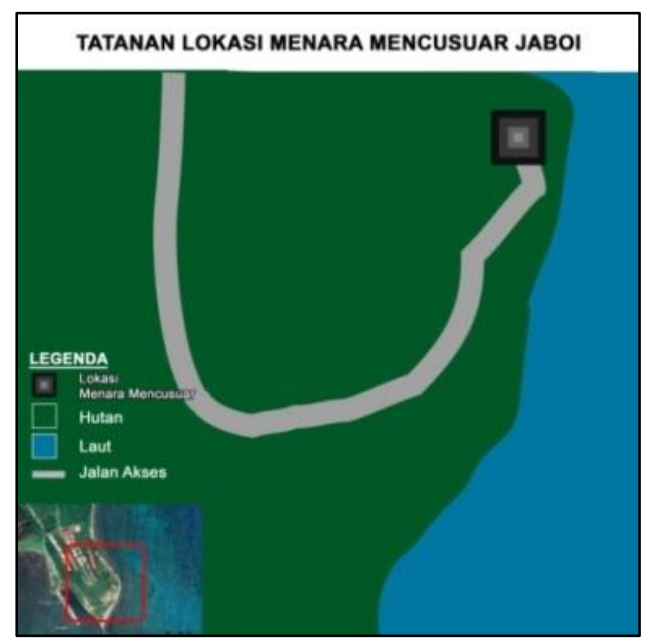

Gambar 9. Tatanan Objek wisata Menara Mercusuar

\section{Tatanan objek wisata Taman Pasi}

Tatanan objek wisata Taman Pasi Jaboi ini sangat stategis wisatawan dapat melihat panorama laut dan area bermain, fasilitas objek wisata Taman Pasi menyajikan area bermain, gazebo, menasah dan kantin.

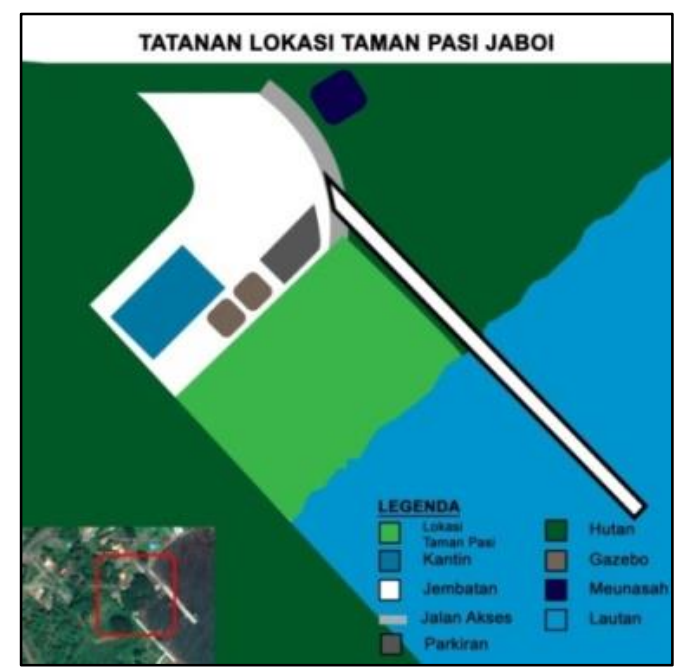

Gambar 10. Tatanan Objek wisata Taman Pasi Jaboi

\subsection{Ruang Konstelasi}

\section{Ruang Objek Wisata Pemandian Air Panas}

Ruang kolam air panas yang pertama yaitu untuk remaja, dewasa dan anak-anak, kolam air panas ini dibuat dengan kedalaman lebih kurang satu meter air yang dimasukkan ke dalam kolam air panas dari Gunung Berapi. Ruang kolam air panas yang kedua ini paling sering digunakan untuk wisatawan lokal maupun mancanegara, kolam ini sering digunakan oleh warga lokal untuk terapi dan pengobatan kaki yang sakit.

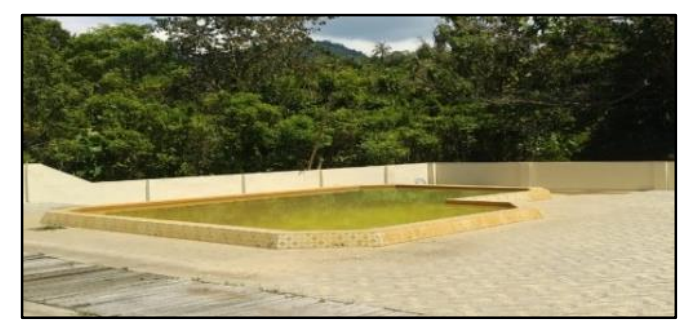

Gambar 11. Kolam Pemandian Air Panas Remaja 


\section{Ruang Objek Wisata Gunung Berapi}

Kawah satu Gunung Berapi di dalam kawah satu ini belum terlihat kawah Gunung Berapi, di kawah satu hanya terdapat belerang dan lubang - lubang bekas lumpur. Di dalam kawasan kawah dua ini mulai terlihat kawah lumpur yang masih aktif, pada objek wisata kawasan tiga terdapat kawah lumpur yang besar dan mengeluarkan asap, Pada kawah empat ini kawah yang terakhir dalam kawasan Gunung Berapi kawah empat terdapat lubang kawah yang besar berisi lumpur.

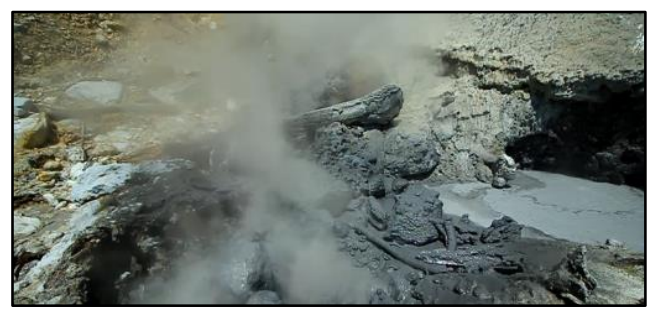

\section{Ruang Objek Wisata Wonderfull Point}

Gambar 12. Kawah Gunung Berapi

Ruang objek wisata ini menyajikan panorama laut dan hutan lindung yang dapat dinikmati oleh wisatawan yang berkunjung dan dapat menikmati matahari terbenam.

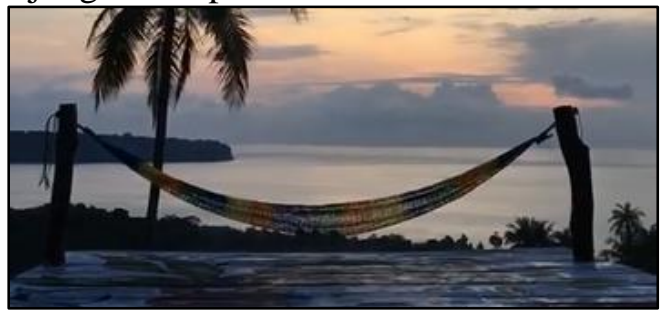

Gambar 13. Objek wisata Wonderfull Point

\section{Ruang Objek Wisata Pantai Batee Tamon}

Wisata ini menyajikan Panorama laut dan terumbu karang bawah laut, menikmati dengan duduk di area pinggiran laut serta bisa mencoba Snorkeling atau Scuba Diving pada area kawasan wisata Pantai Batee Tamon.

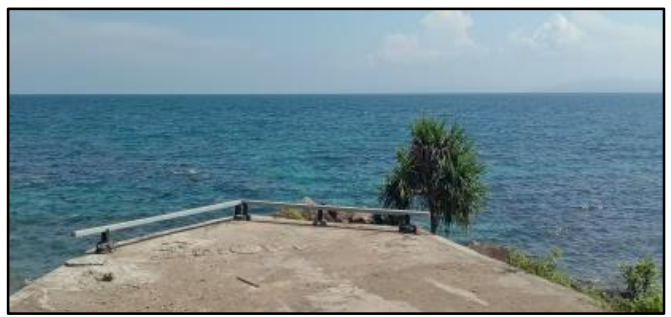

Gambar 14. Objek wisata Pantai Batee Tamon

\section{Ruang Objek Wisata Menara Mercusuar}

Ruang wisata Menara Mercusuar menyediakan tempat ruang sebuah menara yang dapat melihat pemandangan laut, gunung, hutan lindung dan matahari terbit, Menara atau tower yang terletak pada tepi tebing merupakan menara besi mercusuar.

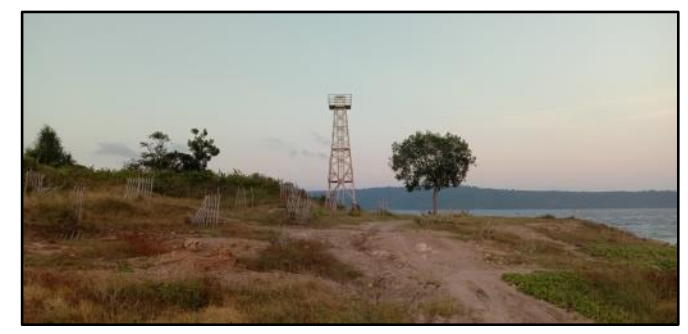

Gambar 15. Objek wisata Menara Mercusuar PROGRAM STUDI ARSITEKTUR UNIVERSITAS MALIKUSSALEH 


\section{Ruang Objek Wisata Taman Pasi Jaboi}

Taman Pasi Jaboi ini menyediakan ruang terbuka dan ruang bermain untuk kalangan anak anak sehingga wisatawan bisa menikmati saat berkunjung ke dalam wisata tersebut. Ketersediaan fasilitas di dalam kawasan wisata Taman Pasi yaitu gazebo, area parkir, ruang buku bacaan, area tempat duduk atau lesahan, serta kantin.

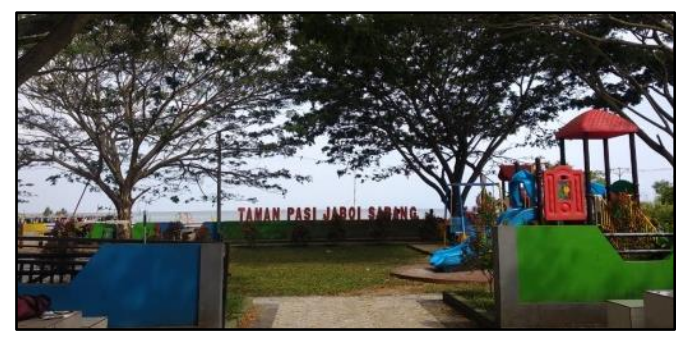

Gambar 16. Objek Wisata Taman Pasi

\section{Pola Konstelasi}

Pola kawasan wisata Gampong Jaboi pada pola ini dapat dilihat beberapa objek wisata, penjelasan untuk masalah tidak tersusun dapat di lihat bahwa menyebarnya beberapa objek wisata sehingga tidak adanya wisata yang saling berkaitan, sehingga penyambungan antara objek wisata yang satu dengan lainnya menggunakan teori konstelasi atau yang disebut bahasa pola, dari pola tersebut maka akan menghasilkan pola-pola seperti pola pergerakan kendaraan dan pejalan kaki lima [9]. Menentukan pola konstelasi pada objek wisata dalam kawasan wisata Gampong Jaboi dapat digabungkan dengan objek wisata laut dengan objek wisata yang serupa, objek wisata gunung dengan objek wisata yang serupa, objek wisata taman dengan objek wisata yang serupa dan objek wisata dengan pemanfaatan yang berada di dalam objek tersebut dengan objek wisata yang serupa [10], sehingga pola konstelasi yang terjadi diantara objek tersebut menjadi 4 (empat) pola konstelasi diantaranya objek wisata pantai yaitu objek wisata Pantai Batee Tamon dan objek wisata Menara Mercusuar, objek wisata Gunung yaitu objek wisata Gunung Berapi dan objek wisata Wonderfull Point, objek wisata taman yaitu objek wisata Taman Pasi dan objek wisata Pemandian Air Panas, objek wisata dari hasil pemanfaatan wisata alam sebagai area pemandian bagi wisatawan yang berkunjung yaitu objek wisata Pemandian Air Panas dan objek wisata Pantai Batee Tamon.

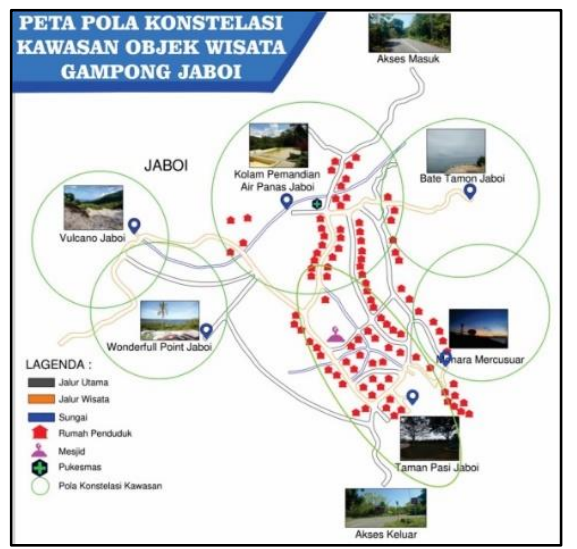

Gambar 17. Pola Konstelasi Kawasan Pada Objek Wisata Dalam Kawasan Wisata Gampong Jaboi

PolaKonstelasi dari hasil pengelompokkan wisata laut/pantai yang terdapat pada objek wisata Pantai Batee Tamon dan objek wisata Menara Mercusuar

Pola konstelasi dari hasil pengelompokkan wisata laut/pantai yang berada dikawasan wisata Gampong Jaboi, dari survei secara langsung dapat disimpulkan bahwa pola konstelasi ini terikat karena adanya persamaan objek wisata seperti kedua objek wisata Pantai Batee Tamon dan objek 
wisata Menara Mercusuar tersebut menampilkan objek wisata laut/pantai sehingga dapat di simpulkan bahwa kedua objek tersebut menghasilkan suatu pola konstelasi.

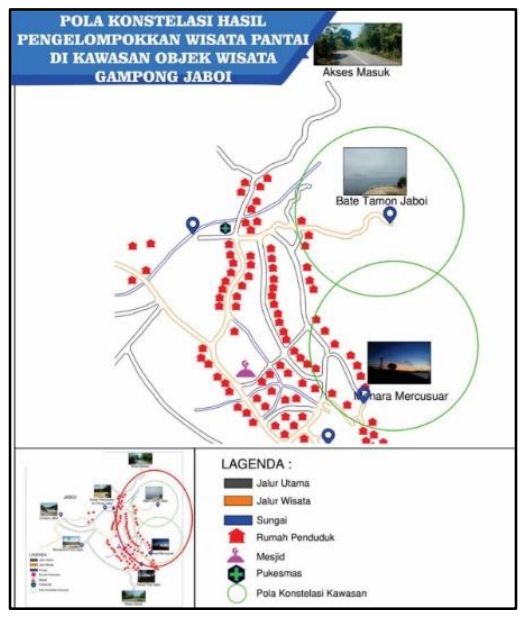

Gambar 18. Pola Konstelasi Hasil Pengelompokkan Wisata Pantai di Kawasan Objek Wisata Gampong Jaboi

Pola konstelasi hasil pengelompokkan wisata gunung yang terdapat pada objek Gunung Berapi dan objek wisata Wonderfull Point

Pola konstelasi hasil dari pengelompokkan objek wisata gunung yang berada di dalam kawasan objek wisata Gampong, dari survei secara langsung dapat disimpulkan bahwa objek wisata ini memiliki objek wisata yang bersamaan seperti kedua objek wisata Gunung Berapi dan objek wisata Wonderfull Point menampilkan objek wisata berupa wisata gunung, objek wisata Gunung Berapi dan objek wisata Wonderfull Point menghasilkan suatu pola konstelasi.

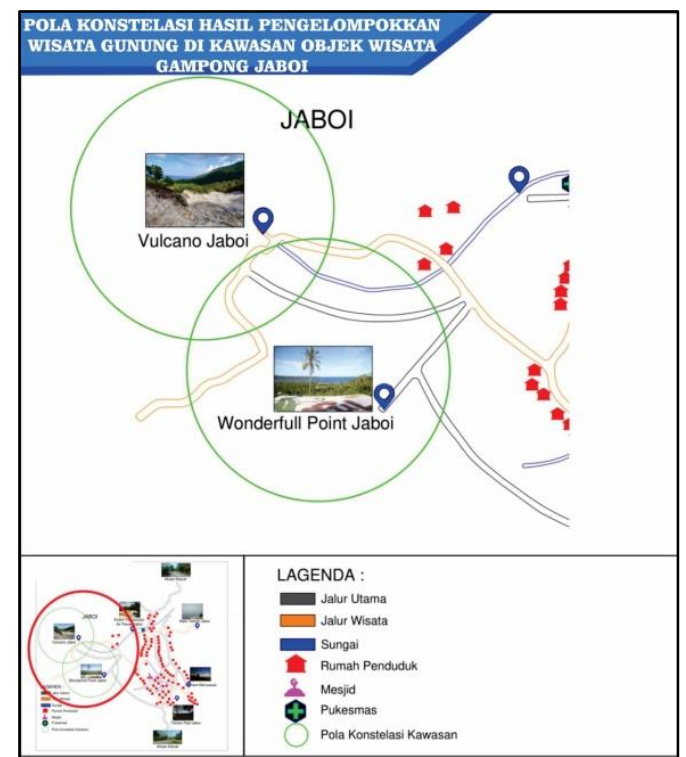

Gambar 19. Pola Konstelasi Hasil Pengelompokkan Wisata Gunung di Kawasan Objek Wisata Gampong Jaboi

Pola konstelasi hasil pengelompokkan objek wisata taman yang terdapat pada objek wisata Taman Pasi dan objek wisata Pemandian Air Panas

Pola konstelasi hasil pengelompokkan objek wisata taman, dari hasil survei secara langsung dapat disimpulkan bahwa pola konstelasi yang saling berikaitan dengan kedua objek wisata tersebut objek wisata Taman Pasi dan objek wisata Pemandian Air Panas terdapat kesamaan objek wisata yaitu memiliki objek wisata taman. Objek wisata keduanya mengabungkan kesamaan terhadap objek wisata sehingga membentuk suatu pola konstelasi. 


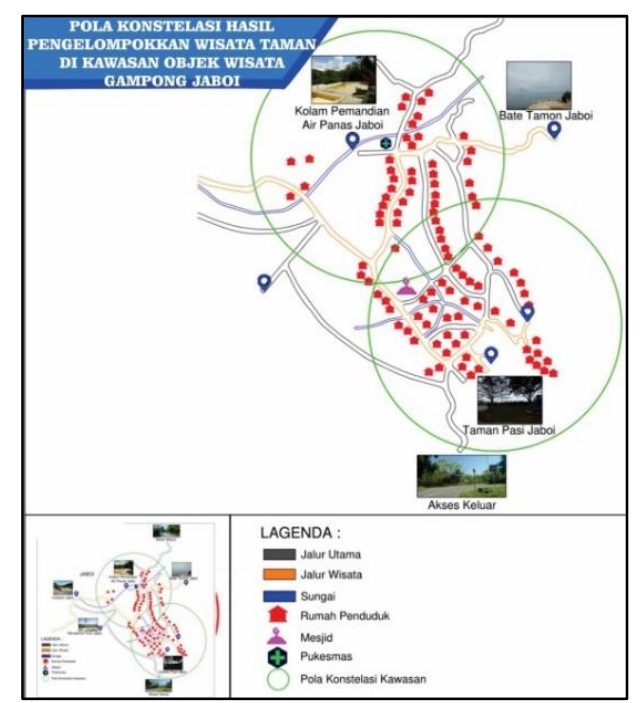

Gambar 20. Pola Konstelasi Hasil Pengelompokkan Wisata Taman di Kawasan Objek Wisata Gampong Jaboi

Pola konstelasi hasil pemanfaatan wisata alam sebagai area pemandian pada objek wisata Pemandian Air Panas dan objek wisata Taman Pasi

Pola konstelasi hasil pemanfaatan wisata alam sebagai area pemandian wisatawan yang berkunjung, hasil survei secara langsung dapat disimpulkan objek wisata Pemandian Air Panas dan objek wisata Pantai Batee Tamon memiliki kesamaan dari hasil pemanfaatan alam.

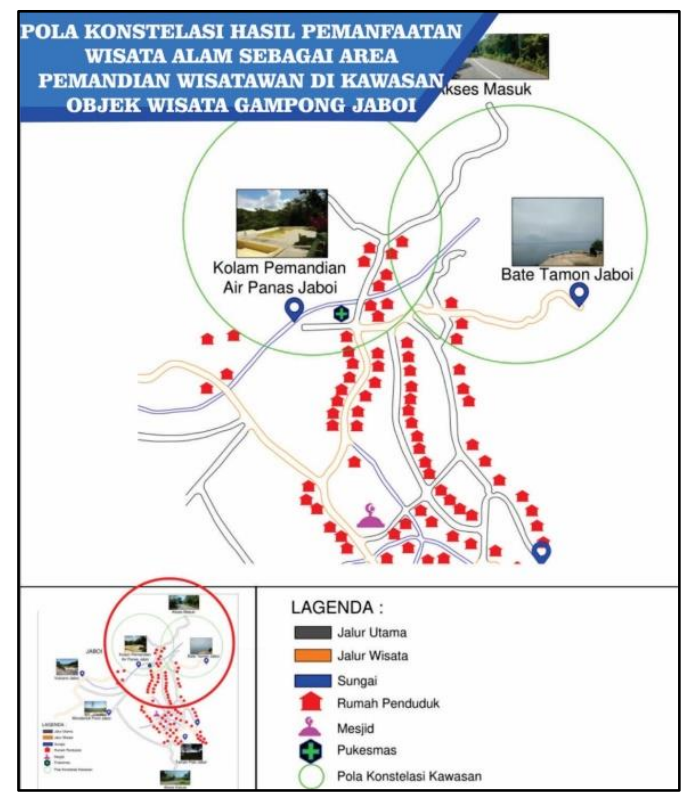

Gambar 21. Pola Konstelasi Hasil Pemanfataan Wisata Alam Sebagai Area Pemandian Wisatawan di Kawasan Objek Wisata Gampong Jaboi

\section{Hubungan konstelasi objek wisata dalam kawasan wisata Gampong Jaboi}

Hubungan konstelasi yang terjadi didalam objek wisata pada kawasan wisata Gampong Jaboi ini banyak sekali, setiap masing-masing objek wisata saling berkaitan atau saling berhubungan baik langsung maupun tidak langsung. Objek wisata yang terlihat memiliki hubungan langsung yaitu objek wisata Pemandian Air Panas dan Gunung Berapi, objek wisata Gunung Berapi dan Wonderfull Point, objek wisata Menara Mercusuar dan Pantai Batee Tamon, objek wisata Menara Mercusuar dan Taman Pasi, dilihat dari teori konstelasi dan hasil survei secara langsung bahwa hubungan konstelasi yang terjadi karena adanya objek wisata yang saling berhubungan baik dari

$$
\text { PROGRAM STUDI ARSITEKTUR UNIVERSITAS MALIKUSSALEH }
$$


panorama maupun rekreasi di dalam objek wisata sehingga membentuk sebuah hubungan konstelasi baik langsung maupun tidak langsung dalam objek wisata.

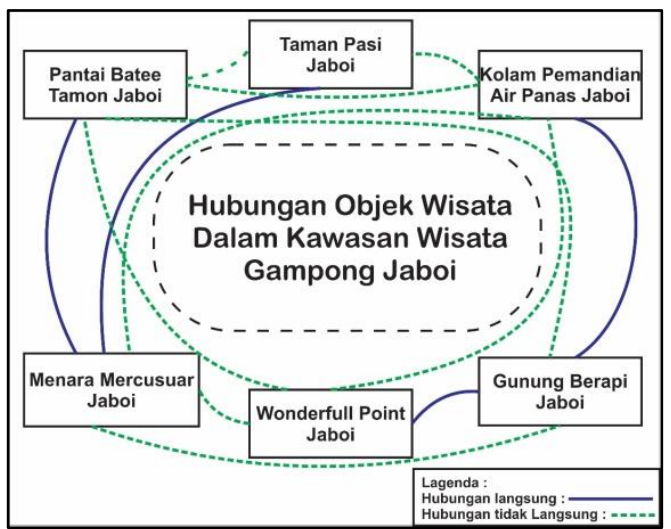

Gambar 22. Hubungan Konstelasi Dalam Kawasan Wisata Gampong Jaboi

\section{KESIMPULAN DAN SARAN}

Hasil dari penelitian ini dapat disimpulkan bahwa konstelasi penataan baik dari susunan dari kawasan objek wisata Gampong Jaboi sudah tersusun sangat bagus, untuk tatanan objek wisata Gampong Jaboi tertata mengikuti kawasan objek wisata, untuk bentuk dari kawasan objek wisata terbentuk secara alami, ruang dalam objek wisata sudah terpenuhi untuk setiap objek wisata. Pola pada kawasan objek wisata Gampong Jaboi terbentuk empat pola berkaitan, dan untuk hubungan pada kawasan wisata Gampong Jaboi terbentuk dari segi panorama maupun rekreasi di dalam objek wisata. Setelah terbentuknya pola konstelasi pada kawasan wisata tersebut, selanjutnya dapat menentukan pola kunjungan wisata yang berada di lokasi tersebut. Misalnya ketentuan jarak suatu lokasi, maka cara untuk menemukan pola konstelasinya akan dimulai dari jarak terdekat sampai jarak terjauh, dan yang kedua adalah terkait dengan biaya yang harus dikeluarkan oleh wisatawan yang akan berkunjung ke sabang, maka wisatawan tersebut akan memilih kunjungan yang akan dituju. Maka fungsi dari konstelasi adalah dapat menentukan jalur wisatawan secara keseluruhan.

\section{DAFTAR PUSTAKA}

[1] Bappeda, "Rencana Tata Ruang Wilayah Kota Sabang," p. 22, 2012, [Online]. Available: http://pekerjaanumum.sabangkota.go.id.

[2] F. Hayatul Mardiah, Monawati, "Hubungan Kecerdasan Spasial Terhadap Hasil Belajar Matematika Materi Bangun Ruang Siswa Kelas 5 SD Negeri 5 Banda Aceh,” vol. 2, pp. 48-60, 2017.

[3] I. Mentayani and P. R. Muthia, "Menggali Makna Arsitektur Vernakular: Ranah, Unsur, dan AspekAspek Vernakularitas," pp. I109-I116, 2017, doi: 10.32315/ti.6.i109.

[4] A. N. Nerustia, R. Rahmawati, and D. Hernawan, "Implementasi Kebijakan Pengelolaan Tata Ruang Wilayah Konservasi Dan Pariwisata," vol. 1, no. 54, pp. 2442-3971, 2015, [Online]. Available: https://unida.ac.id/ojs/index.php/JGS/article/viewFile/295/50.

[5] G. Suwantoro, Dasar-Dasar Pariwisata. Yogyakarta, 1997.

[6] F. Kalebos, "Faktor-Faktor Yang Mempengaruhi Kepuasan Wisatawan Yang Berkunjung Ke Daerah Wisata Kepulauan,” J. Ris. Bisnis Dan Manajem, vol. 4, pp. 489-502, 2016.

[7] M. C. E. Wahyu Narendra Kusuma Wardana, Agung Witjaksono, "Identifikasi Kebutuhan Sarana Dan Prasarana Wisata Berdasarkan Persepsi Pengunjung Di Pantai Sipelot Kabupaten Malang," pp. $1-13,2018$.

[8] R. P. Mokodongan, D. M. Rondonuwu, and I. L. Moniaga, "Evaluasi Rencana Tata Ruang Wilayah Kotamobagu Tahun 2014 - 2034,” Spasial, vol. 6, no. 1, pp. 68-77, 2019.

[9] F. D. K. Ching, Arsitektur Bentuk Ruang dan Tatanan. Jakarta: Erlangga, 2008.

[10] Y. Priono, "Pengembangan Kawasan Ekowisata Bukit Tangkiling Berbasis Masyarakat," $J$. Perspekt. Arsit., vol. 7, no. 1, pp. 51-67, 2012. 